\title{
HISTORY OF THE NATURAL HISTORY OF SABLE ISLAND
}

\author{
IAN A. MCLAREN* \\ Department of Biology, Dalhousie University \\ Halifax, NS B3H 4J1
}

\begin{abstract}
Documenting of natural history flourished with exploration of remote parts of North America during the late 18th and early 19th centuries, but the earliest published observations on the biota of Sable Island, along with casual observations in the journals of successive superintendents are vague, and emphasize exploitability. John Gilpin's 1854 and 1855 visits were the first by a knowledgeable naturalist. His published 1859 "lecture" includes sketchy descriptions of the flora, birds, pinnipeds, and a list of collected marine molluscs. Reflecting growth of 'cabinet' natural history in New England, J. W. Maynard in 1868 collected a migrant sparrow in coastal Massachusetts, soon named Ipswich Sparrow and recognized as nesting on Sable Island. This persuaded New York naturalist Jonathan Dwight to visit the island in June-July 1894 and produce a substantial monograph on the sparrow. He in turn encouraged Superintendent Bouteiller's family to send him many bird specimens, some very unusual, now in the American Museum of Natural History. Dominion Botanist John Macoun made the first extensive collection of the island's plants in 1899 , but only wrote a casual account of the biota. He possibly also promoted the futile tree-planting experiment in May 1901 directed by William Saunders, whose son, W. E., published some observations on the island's birds, and further encouraged the Bouteillers to make and publish systematic bird observations, 19011907. This account closes with Harold St. John's 1913 stay on the island and his first truly modern treatment of the island's flora in 1921. Little more was added before modern biological research was initiated, arguably with censuses and biological sampling of seals in the early 1960s.
\end{abstract}

\section{INTRODUCTION}

The study of natural history in North America during the late 18th and early $19^{\text {th }}$ century was largely an interest of the leisured class and the military. Their collections of minerals, pressed plants, and 'cabinets' of mollusc shells, pinned insects, and mounted birds and mammals were marks of education and commitment, and in the military, probably an attempt to escape boredom. Novelties also flowed in from explorations of North America beyond the limits of

* Author to whom correspondence should be addressed: i.a.mclaren@dal.ca. 
European settlement. Illustrated books and sets of plates illustrating this natural diversity became available to the moneyed public (e.g. birds by Wilson 1808-1814; plants by Barton 1821-1823; invertebrates by Say, $1824-28 ; 1830-1834)$. By the mid- $19^{\text {th }}$ century, natural history museums were established as both commercial and public enterprises (e.g.: Smithsonian Institution 1846; natural history collections of the Geological Survey of Canada beginning 1856, now in Canadian Museum of Nature; Nova Scotia Museum of Natural History 1868). Throughout this time, Sable Island was well known as a special place, but its flora and fauna were only casually recorded, and Nova Scotian John Gilpin was the first knowledgeable naturalist to visit the island (Gilpin 1858).

Brief histories of our knowledge of the Sable Island biota have been given by others, most exhaustively by: St. John (1921); and for vascular plants, Catling et al. (1985); invertebrates, Howden et al. (1970); birds, Stobo and McLaren (1975), and McLaren (1981a). The present account adds no new sources of information. It does, however, attempt to situate these early studies in the wider contexts of those times.

\section{THE EARLIEST ACCOUNTS}

Patterson's (1894) well-known monograph reviewed the history and geography of Sable Island up to his time. Most subsequent papers on its natural history have referred to Patterson's summaries of early descriptions of the landscapes, plant cover, and biota. The pre- $19^{\text {th }}$ century accounts mention its plant cover, feral domestic mammals, and its wildlife, mainly seals and walruses and occasionally waterfowl and seabirds, but almost nothing other than these exploitable animals. Oddly, the most wide-ranging early description of the biota is in an advertisement in The Boston Weekly News Gazette (1737; available online and also given in full by St. John 1921) by Andrew LeMercier, Huguenot "pastor of the French church". He lists "The Island Sables" ... to be sold by me" and provides "a short description of it for nothing." Its natural features are described with advertising hyperbole:

“. . . medicinal plants ... no venomous creatures ... nearly 20 sorts of berries . . . very good liquors and wines might be expressed ... beach pease, which fatten the cattle very 
well ... Providence hath opened .... the Great Pond ... with flounders and eels . . . the beach itself with clams and sand eels ... the air with fowls ... to make money with their feathers . . .soil natural for roots . . . especially turnips ... uncommonly sweet ..."

Apparently having requested title to the island from the Crown, LeMercier placed his agents there and stocked it with livestock, later plundered by others. Haliburton $(1829$, p. 269) notes that the grant was declined with failure to pay quit-rent for the privilege. Unsurprisingly, it was not sold.

Nothing new was documented until 1801, when the island became permanently occupied. A description of its natural bounty was in an 1801 report to Governor Sir John Wentworth by Capt. Jones Fawson, of the armed brig Earl of Noira, after delivering building materials and supplies for the new Sable Island establishment (quoted by Murdoch 1867, p. 214).

"The Island is capable of supporting a large stock of cattle . .. well watered and covered by a kind of sedge grass. . . and an immense quantity of wild peas which the cattle can feed upon summer and winter as the . . whole surface is exposed to the sea air, which speedily dissolves the snow ... . a variety of wild berries and cran berries, the latter . . . in profusion ... the pond contains lobsters and other shell fish besides eels, flounders, perch, etc., and in season is frequented by blue-winged ducks [=American Black Duck, Anas rubripes] and other wild fowl in abundance."

After a winter on the island, Superintendent Morris's first report to the authorities, March 29, 1802, was less glowing: "I never saw wild fowl so scarce in any part of America near the ocean as at this island ..."

For the next half century, we have to depend largely on the journals of the island's superintendents for snippets of information on the biota, which must largely be gleaned from those kept in the Nova Scotia Archives (an exception is the recently published journal by the founding superintendent, James Morris (2001). These journal entries usually involved exploitation of, or competition for, food supplies, e.g.: 
James Morris, Nov. 21"st 1802: "large Sea Clams . . found on the North Beach ... are excellent eating, but ... the large gulls after a gale out sail us and often leave us only the shells." (Of interest because gulls did not breed on the island then, but did appear in winter.).

Edward Hodgson, Sept. 30" 1810 : "We tried to raise some Oats, and had a very good appearance, but a small bird we call the grey bird Destroyed the whole." (First known mention of the Ipswich Sparrow, albeit as a pest.).

Joseph Darby, May 6" $, 1845:$ "The Mackerel gulls made their first appearance today, an index of a backward spring." (Mackerel gulls, or sometimes 'small gulls', were terns, often mentioned because their eggs were heavily exploited, with later reports of up to nearly 40 buckets filled.).

There were also more insidious assaults on nature:

James Morris, March 25 ${ }^{\text {th }}$, 1802: "I set fire to the grass [which] spread ... with great violence. The ships people [shipwreck survivors] by my desire has burnt clean about 2000 acres ..."

Matthew McKenna, April 1 ${ }^{\text {st }}-5^{\text {th }}, 1854$ "Much breaking up of sod."

A few visitors or employees on the island before mid-century commented on the general features of the island, including its plant cover and wildlife, but added nothing that was not already well known (see reviews by St. John 1921 and others). One entertaining source is the published memoir of James Augustus Farquhar (1980; his Sable Island entries published earlier by Martin 1946), who spent the years 1849-1863 as the young son of the keeper of the "Eastern Establishment" (later "East Light"). He includes commonplace comments on the terrain and plant cover, birds (see McLaren 1981, p. 5). The original memoir is not dated in either published source (Farquhar died in 1930), but his Sable Island memories are clearly clarified and augmented by later experiences. (See comment below following Gilpin's misidentifications of the island's Grey Seals).Also beginning in the mid- $19^{\text {th }}$ century, publications on the island's natural history began to flow from visits by naturalist, and the following review is based on those primary sources. 


\section{VISITS BY J. BERNARD GILPIN, 1854, 1855}

John Bernard Gilpin (1810-1892) was a significant figure in $19^{\text {th }}$ century Nova Scotia (Biography http://www.biographi.ca/en/bio/ gilpin_john_bernard_12E.html>.). He practiced medicine in several parts of the province, but his avocation was natural history. In that role, he was one of the founders of the (present) Nova Scotia Institute of Science and a foundation member of the Royal Society of Canada. Nonetheless, there is some carelessness in his publications on birds of Nova Scotia compared to some earlier accounts (McLaren 1981b).

Gilpin first visited on the island in Spring-Summer 1854, but did not mention dates in his published "lecture" on the island (Gilpin 1858; see below), or in his subsequent publications. However, Superintendent McKenna's Journal of 5 May 1854 states that "Dr. Gilpin comes on in the [supply vessel] Daring and arrives here for a while." In a 30 June letter to the Hon. Hugh Bell, Chairman of the Board Of Works, Halifax, McKenna wrote: "I am sorry to say that Dr. Gilpin cannot leave the island yet, nor can I say when it is even probable that he can"; this was despite three recorded departures of supply vessels for Halifax in the interim, perhaps indicating a certain weariness of his guest. Finally, Acting Superintendent James Farquhar's Journal recorded Gilpin's departure (with McKenna on leave) 22 July 1854. Entries in the Superintendent's Journal also record another brief visit by Gilpin 1-5 September 1855.

Gilpin's (1858) monograph on the "history, appearance, and natural history" of the island includes descriptions of the biota that seem more ornamental than scientific, and include some inaccuracies. For example: "A Botanist would ... list thirty or forty varieties [a serious underestimate] of shrubs and plants ... dwarfed ... with-wood would not afford a riding-cane. Tall grasses cover the surface ... alternating with sandy barrens ... Wild rose, blue lily, and wild pea enamel the valleys ... and as Autumn heats yellow the luxuriant green, the tall mallow, gay golden rods and wild China-asters are swept by heaving gales." His list of fishes is perfunctory: “... usual varieties of the Cod . , , are found about the soundings ... and Mackerel ... are plentiful ... Flat Fish and Eels are found in the lake, and the remains of monstrous Skate, destroyed by the Seal ..." His account of the Grey Seal (Halichoerus grypus) mistakes it for the arctic Bearded Seal (Erignathus barbatus): "During January the great Greenland seal (Phoca barbata $[$ sic]) leaves his frozen seas ... to rear his little ones... old males ... 
eight or nine hundred weight, and readily recognized by their bristling moustache." Later [Gilpin 1869] he recognized it correctly as more likely the Grey Seal.It is also correctly identified as "horse-head" seal, a common vernacular, in Farquhar's (2001) memoir. Farquhar was present as a child on the island during Gilpin's visits, but of course his correct identification must have been informed by his later years as a sealing captain. Gilpin also noted that the Grey Seals "if undisturbed ... remain till Spring; but if molested, they ... soon disappear." This contrasts with the undisturbed thousands summering there today. He recorded a few birds, not recognizing the "little brown Sparrow, (Fringilla) [that] summered and wintered there" as different from the mainland Savannah Sparrow. He also refers to unusual past sightings of summering Snowy Owls (Bubo scandiacus), and then writes "it is curious to watch this powerful bird standing in August sun ... as he watches by the side of a rabbit burrow: his fondness for game being too strong for his northern instinct", but does not make it clear if this was personal observation or for enlivenment of his "lecture". Gilpin also included a few more birds reported subsequently from the island in other publications (detailed in McLaren 1981a).

There is no record that Gilpin collected biological specimens during his visit other than beach shells, of which he confessed: "I am not Conchologist enough to classify the various Shells ..." He did, however, have them identified by educator and accomplished amateur conchologist, John R. Willis of Halifax, another founder of the Nova Scotia Institute of Science. Willis wrote a list (p.58 in Gilpin 1858).of these molluscs including a tube-building annelid and an echinoderm. Notable among them were "Pecten concentricus", later changed to $P$. irradians by Jones (1877) and now recognized as a distinct subspecies of the Bay Scallop, Aquaepectin irradians sablensis, well north of the present range of the species from Cape Cod south. (Clarke 1965). A few recently collected shells of it and the American Oyster (Crassostrea virginica, listed by Willis as "Ostrea borealis") were radiocarbon-dated respectively as from 1432-1800 and 3630-5650 years before 1950, indicating to Clarke et al. (1967) that they had arrived during warmer climatic periods. Neither has been found alive or freshly dead on Sable Island or its surrounding waters in recent years, but they could have long survived in the large and presumably warmer lagoon of the island, that later became "Lake Wallace", which has disappeared in recent years. The small scallop was unlikely to 
have been sought as food, and I have not found references to oysters in superintendents' diaries.

\section{VISIT BY JONATHAN DWIGHT, 1894}

New York physician and naturalist, Jonathan Dwight was the next naturalist to visit the island. He exemplifies the evolution of a more sophisticated 'cabinet' natural history, in the latter half of the $19^{\text {th }}$ century. His kind were driven by the urge to collect and classify (thoroughly Linnaean by then), but were often informed by Darwinism and more given to study nature in situ. In North America, this change was centred in New England, and was fostered by the founding of organizations and journals for documentation of records and information (including the Nova Scotian Institute of Science and its Proceedings and Transactions). McLaren and Horn (2006) give some background on Dwight and his times. The development of modern field ornithology and the avocation of birding in this era are vividly described by Lewis (2012).

Massachusetts naturalist Charles Johnson Maynard made a living by collecting and selling specimens, mainly birds, and lecturing and writing on natural history. He was also a pioneer birder who "taught countless students ... to use their eyes and ears instead of a gun to identify birds" (Abele 2002). Dwight's Sable Island visit directly stemmed from Maynard's collection of a sparrow on a coastal beach at Ipswich, Massachusetts, in December 1868 and his later recognizing it as a distinct species (Maynard 1872). The Ipswich Sparrow (now taken as a subspecies of the Savannah Sparrow, Passerculus sandwichensis princeps) soon became known as a regular winter resident and migrant along the US Atlantic Seaboard. An indication of its breeding place began with Ridgway's (1884) discovery of eggs in the U.S. National Museum that had been sent from Sable Island in July 1863 by Superintendent Dodds. These appeared to be a larger version of the mainland Savannah Sparrow's eggs, and a request for specimens of the "grey bird" of the island confirmed it as the Ipswich Sparrow (Merriam 1884).

All this inspired New York physician and naturalist Jonathan Dwight's visit to the island 28 May to 14 June 1894, specifically to study the sparrow, including its breeding biology and other characteristics. His excellent monograph (Dwight 1895) includes a review of existing information on the island and his own assessments. 
He appears to have been the first actually to collect plants there, and he had some pre-flowering ones identified by well-known botanist N. L. Britton of Columbia College (Dwight 1895, p. 12-13). This collection was reviewed by St. John $(1921$, p. 36) who, knowing the contributions of all others, rated Dwight as "the first naturalist to visit the island".

Dwight's collections of several hundred bird specimens from Nova Scotia, now in the American Museum of Natural History, are listed and discussed by Buckley and McLaren (2014). Among these are 267 specimens of 107 species from Sable Island, mostly sent to Dwight by the Bouteillier family between 1894 and 1904, all of them included by McLaren (1981a; see below; and note correct holographic spelling of the Bouteillier name, frequently misspelled in published references.) A few have been found in other museums, and there probably more housed elsewhere. The specimens, including the first Barolo Shearwater recorded in North American (as "Little Shearwater", now Puffinus baroli), and several firsts for Nova Scotia and Canada, were early indications that the island is a paramount eastern North American haven for vagrant birds from afar (cf. McLaren 1981b).

Dwight also developed an important relationship with Superintendent Bouteillier's family, encouraging daughter Beatrice ("Trixie") and sons, James and Robert to observe and collect and prepare specimens of the island's birds. A copy of a letter sent by Dwight on the $25^{\text {th }}$ of May, 1901, to "DearTrix" (courtesy Robert S. Bouteillier, Saanichton, BC) marks this relationship:

"A fine letter from you came about the middle of March . . . I also got your father's letter in March \& Dick's \& also a batch in early January with a nice lot of bird skins . . . there is hardly a bird you send that does not interest me ..."

Dwight's lasting influence is also evident in a radio interview by Trixie Bouteillier in her late 90's, in which she recalled Dwight's visit and recited some scientific names of birds she had learned at the time (McLaren 1981a, p. 6). 


\section{VISIT BY JOHN MACOUN, 1899}

John Macoun (b. 1831, d. 1920) was an important figure in Canadian natural history (posthumous autobiography by Macoun 1922; biography by Waiser 1989). During the 19th century, along with the rise of 'cabinet natural history', naturalists became attached to explorations on the grand scale as part of the assessment by nations of new and supposedly under-occupied lands. Charles Darwin is iconic, and Macoun an example within Canadian bounds. Macoun developed his knowledge of botany during his days as a teacher in Ontario, and became recruited for this skill in 1872 to join surveys in western Canada for railway routes and to assess the potential for agriculture. This led to his appointment as Dominion Botanist by the Geological Survey of Canada, which licensed him for botanical surveys throughout the country. According to Waiser (2009, p. 137) Macoun was authorized by the Survey's director G. M. Dawson " 'to gather facts on the economic potential or agricultural value of the soils' of New Brunswick and Sable Island, 'as indicated by the plants or otherwise' ". His visit to Sable Island in 1899 was the first by a professional naturalist. His autobiography (Macoun 1922, p. 279) states that: "Early in July I embarked for Sable Island" and "I spent nearly three months as a guest of the Superintendent." However, his Annual Report that includes his 1899 visit (Macoun 1902) is presumably more accurate in stating that he arrived 20 July and spent five weeks there. Unfortunately, Robert Bouteillier's 1899 journal, which would have recorded those dates, is not among those in the Nova Scotia Archives.

Macoun (1902) sketched some general features of the island's plant cover. ${ }^{1} \mathrm{He}$ also named some plants that he encountered and stated that he collected "Of flowering plants, 101 species. . . and nearly one-hundred of cryptograms ... I have not had time to determine all the species ..." He did not publish a separate list of the plants, but included some in later parts of his Catalogue of Canadian Plants (Macoun 1883-1902), and his vouchered specimens have been reassessed in subsequent studies (St. John 1921, Catling et al. 1985, Richardson et al. 2009).

\footnotetext{
Note that every reviewer since has evidently used St. John's (1921) almost complete copy of Macoun's comments rather than the original, as indicated by their use of the reference given by St. John as "Annual Report of the Canadian Geological Survey". Perhaps this was by analogy with the "U.S. Geological Survey", instead of "Geological Survey of Canada" as correctly referenced here.
} 
Macoun (1902) also reported that the island's "fresh-water ponds contain a few small fishes", but did not mention his most interesting find, a freshwater sponge described soon after by Mackay (1900) as Heteromayenia macouni, and now taken as a junior synonym of the widespread Racekiela ryderi (van Soest et al. 2010). He paid more attention to insects, noting that: "A few insects were collected including beetles, butterflies, moths and dragonflies [and as] soon as time will permit, all the collections will be worked up," He did not fulfill this intention, and no specimens of insects or other invertebrates collected by Macoun (except the sponge) are mentioned in the compendia by Howden et al. (1970) or Wright (1989). They also do not mention his "collection of marine invertebrates" from Sable Island said to have been deposited in the Survey's museum (Annual Report Geological Survey of Canada 1999, p. 206A).

Macoun (1902) remarked only briefly on birds, seals, the extinct walrus, and feral mammals, and made no mention of collecting birds. However, pairs of the Ipswich Sparrow and the three tern species were listed as donated to the Survey's museum in the same Annual Report (p. 206A). Sable Island birds also received some mention in his Catalogue of Canadian Birds with his son (Macoun and Macoun 1909), which includes his personal observations of breeding Piping Plover,Least Sandpiper, the three tern species, and the Ipswich Sparrow, which he would have seen during his summer visit. The Catalogue does not include some unusual species recorded by the Bouteilliers, and some collected for, but not published by Dwight, including first records for Nova Scotia and Canada (see above).

Waiser's (1989) biography of Macoun stresses his great energy and skill as a collector of specimens throughout Canada, but also his failings in cataloguing, identifying and classifying his finds, which he left almost entirely to others. His scant and deficient publications on Sable Island biota appear to match that assessment. His rather flowery message in the Bouteillier's visitor's book (see McLaren 1981a) expressed another aspect of his personality:

"To the young people I may, as a teacher, say go on as you are doing and, though shut out from the world and all its vanities and follies, you are not shut out from nature which if taken aright is the best teacher and the one that when accepted as a guide is the best teacher." 
This seems to reflect a very different relationship with the family compared to the more concrete encouragements by Jonathan Dwight (see above) and W. E. Saunders (see below). Finally, in keeping with his mandate, Macoun's (1902) annual report praised Superintendent Bouteillier's techniques for subsistence farming on the island, mused about the past existence of trees on the island, and recorded the difficulties of sustaining deciduous ones. Nonetheless, he concluded that "Spruce or other conifers would perhaps do better and the experiment is worth trying."

\section{VISIT BY WILLIAM SAUNDERS AND SON, 1901}

Given the comments in his Annual Report on the possibility of planting conifers (see above), it might seem that Macoun encouraged the Minister of Marine and Fisheries to request that William Saunders (Ottawa Director of the Dominion Experimental Farms system) undertake consider the tree-planting experiment of summer 1901 (see St. John 1921, p. 47). However, Macoun's (1922) posthumous autobiography (p. 279) implies otherwise that: "my report was discounted . . . and, three years after they [the planted trees], were all gone and my report was evidently accepted." This is a memory lapse or possibly based on an unpublished "report". The futile afforestation enterprise is well assessed by St. John (1921).

Of interest here are the contributions of Saunders' son (also William [Edwin]), later a businessman and active naturalist living in London Ontario, who accompanied his father to the island and stayed there 16-23 May (Saunders 1902) In an editorial foreword to his newspaper account of the island and its biota (Saunders 1901), the young Saunders, was said to have been "less interested in the forestry experiment than in the birds of the island" and he subsequently published three notes on its birds (references in McLaren 1981a). More importantly, he cultivated the friendship of the Bouteillier family, and McLaren (1981a, p. 8) gave evidence that a brief list by son Richard of "birds seen in autumn 1901" was sent to W.E. Saunders, who expedited its publication (Bouteillier 1901). Thereafter, probably triggered by that publication, a series of hand-written lists for 1902 to 1908 were sent to Harry Piers, Curator of the Provincial Museum; all but one are archived in the Nova Scotia Museum of Natural History, and most were published (as listed in McLaren 1981a, Table 1). McLaren (1981a) 
also concluded that the lists were part of a more extensive solicitation by Piers of migration records from other parts of the province, and might be viewed as an early example of citizen science. As noted by McLaren (1981a), some records by the Bouteilliers, even those backed by specimens sent to Dwight, were ignored in later publications on birds of Nova Scotia and Canada, possibly because the many unusual ones seemed suspect.

\section{VISIT BY HAROLD ST. JOHN, 1913}

Botanist Harold St. John visited the island during summer 1913. Dates of his arrival and departure are not given in his monograph on the island's vascular flora (St. John 1921), but he listed plants collected as early as 15 August and as late as 19 September, and Superintendent J.U. Bleakney's diary for that year is not in the NS Archives. The gap between his visit and the publication resulted from his service in World War I, and he went on to have a long distinguished career as a professor of botany in the University of Hawaii and write extensively on the flora of the Pacific Islands.

A slightly earlier visit by H.T. Güssow, 24 August-14 September in 1911 (Superintendent Bouteillier's journal), who was then Dominion Botanist of the Dominion Experimental Farms, Ottawa, produced no publication of his observations or collections, although his plant records and specimens, along with Macoun's earlier ones, were incorporated by St. John and later chroniclers (e.g. Catling et al. 1985).

The Introduction in St. John's (1921) monograph on the island and its vascular plants begins modestly: "In the summer of 1913 the writer made a botanical collecting trip to Sable Island, Nova Scotia." However, St. John was at the time an undergraduate student at Harvard of the renowned botanist M.L. Fernald (biography by Merrill 1954), who published extensively on the flora and phytogeography of the northeastern US and eastern Canada. Accordingly St. John's monograph, in addition to offering excellent summaries and discussions of the past history and prior botanical knowledge of the island, along with a detailed annotated and illustrated list of its vascular plants, was the first to place its flora in a modern phytogeographic perspective. 


\section{DISCUSSION}

This account of the history of natural history of the island closes with the visit and publication by Harold St. John. Erskine (1953) discusses plants he collected there in summers 1952 and 1953, and he and a few other visitors prior to the 1960s recorded the birds they observed (see McLaren 1981a). Collecting and listing of plants and animals continues into recent times, but modern biological research might be said to have been begun when personnel of the then Fisheries Research Board of Canada started visiting beginning in June 1961 to census, brand, and obtain biological samples from seals for studies of their life histories, dispersal and ecological roles (Mansfield and Beck 1977).

Since then, the island has hosted more naturalists and researchers who have produced many more publications, and the island's biotas are surely among the most intensely studied in the world. Why this great attention? The island does offer great advantages for complete cataloguing and detailed studies of conveniently circumscribed populations and communities. But, it also seems clear from the early and continuing interest in such studies that the pleasure of being there is a major motivation. Gilpin (1858), in the opening of his published lecture, puts it thus: "A ROMANTIC interest has always invested the subject of ... Sable Island. Its position, jutting far out into the Western Atlantic, - its wind-swept desolate sand-hills, - its perpetual fringe of everlasting surf, with its sad story of many a drowned man or seawrecked ship, mingled with ghostly fable or truer tale of murderous plunder, - are full warrant for the deepest interest."

Acknowledgements I am grateful to Eric Mills for casting a historian's eye on the manuscript, suggesting a number of improvements. I am also grateful to the staff of the Nova Scotia Archives, Halifax, for their help in accessing the letters and journals of $19^{\text {th }}$ and early $20^{\text {th }}$ century Superintendents of the Sable Island Establishment. 


\section{REFERENCES}

Abele, S. (2002). Discovering Charles Johnson Maynard: Naturalist, and Teacher. Jackson Homestead Museum, Newton, MA. 30 pp.

Barton, W.P.C. (1821-1823). A flora of North America: illustrated by coloured figures, drawn from nature. Philadelphia: M. Carey \& Sons.

Bouteillier, R. (1901). Autumn notes on birds, Sable Island, NS. 1901. Ottawa Nat. 15:199-200.

Buckley, P.A., \& McLaren, I.A. (2014). Jonathan Dwight's collections of Nova Scotia birds in the American Museum of Natural History. N.S. Birds 66 (4):46-50.

Catling, P.M., Freedman, B., \& Lucas, Z. (1985). Vegetation and phytogeography of Sable Island, Nova Scotia. NSIS Proceedings 24: 181-248.

Clarke, A.H.,Jr. (1965). The scallop superspecies, Aequipecten irradians (Lamarck). Malacologia 2(2):161-188.

Clarke, A.H.,Jr., Stanley, D.J., Medcof J.C., \& Drinnan, R.E. (1967). Ancient oyster and bay scallop shells from Sable Island. Nature (London) 215(5106):1146-1148.

Dwight, J. (1895). The Ipswich Sparrow (Ammodramus princeps) and its summer home. Mem. Nuttal Ornithol. Club, No. 2, 56 p.

Erskine, J.S. (1953). The edology of Sable Island. NSIS Proceedings 23:120-145.

Gilpin,J.B.(1858). Sable Island: its Past History, Present Appearance, Natural History, \&c . . . Halifax: Wesleyan Conference Press. 35 p. + 3 illus.

Gilpin, J.B. (1869). The walrus. Proc. Trans. N.S. Inst. Nat. Sci. 2:123-127.

Haliburton, T.C. (1829). An Historical and Statistical Account of Nova Scotia. Vol. II., p. 269.

Howden, H.F., Martin, J.E.H., Bousfield, E.L. \& McAllister, D.E. (1970). Fauna of Sable Island and its zoogeographic affinities - a compendium. Nat. Mus. Can.Publ. Zool., 4, 45 pp.

Jones,J.M.(1877). Molluscs of Nova Scotia,(corrected to date 1877.). Proc. Trans. N.S. Inst. Nat. Sci. 4: 321-330. [1st 3 pp. mis-numbered 421-423].

Le Mercier, A. (1773). The Island Sables. Boston Weekly News-Letter, February 8. 1753.

Lewis, D.J. (2012). The Feathery Tribe: Robert Ridgway and the Modern Study of Birds. New Haven: Yale Univ. Press. 368 pp.

MacKay,A.H.(1900). A freshwater sponge from Sable Island. Proc. Trans. N.S. Inst. Sci. 10:319-322.

Macoun, J. (1902). Sable Island. Geol. Surv. Can. Ann. Rept. 12 (1899): 212A-219A.

Macoun, J. (1922). Autobiography of John Macoun, M.A. Ottawa FieldNaturalist's Club. $\mathrm{x}+301 \mathrm{pp}$.

Macoun, J., \& Macoun, J.A. (1909). Catalogue of Canadian Birds. Dept. Mines. Geol. Surv. Branch, Ottawa. No. 793, vii + $763+$ xiii pp.

Mansfield, A.W., \& Beck, B. (1977). The Grey Seal in Eastern Canada. Env. Can. Fish. Mar. Serv. Tech. Rept. 704. x + 81 pp. 
Maynard, C.J. (1872). A new Passerculus from eastern Massachusetts. Am. Nat. 6: 637-638.

McLaren, I.A. (1981a). The Birds of Sable Island. Proc. NSIS 31:1-84.

McLaren,I.A. (1981b). The incidence of vagrant landbirds on Nova Scotian islands. Auk 98:243-257.

McLaren, I.A. (1986). Survey of $19^{\text {th }}$ Century Ornithology in Nova Scotia. Part 2. Annotated bibliography. N.S. Birds 28(2):71-78.

McLaren, I.A. \& Horn, A.G. (2006). The Ipswich Sparrow: past, present and future. Birding 38 (5):56-63.

Merriam, C.H. (1884). Breeding of Passerculus princeps on Sable Island. Auk 1: 390.

Merrill, E.D. (1954). Merritt Lyndon Fernald, 1873-1950. A Biographical Memoir. National Academy of Sciences, Washington, D.C.

Morris, J.R. (2001). Sable Island Journals 1801-1804. Sable Island Preservation Trust, Halifax, $\mathrm{x}+166 \mathrm{pp}$.

Murdoch, B. (1867). A History of Nova-Scotia or Acadie. Vol. 3. Halifax, James Barnes, Publisher. xv +613 pp.

Patterson, G. (1894). Sable Island: its history and phenomena. Trans. Roy. Soc. Can. 12, Sec. 2:3-49.

Richardson, D.H.S., Lucas, Z., \& Anderson, F. (2009). The lichen flora of Sable Island, Nova Scotia: its past, present and likely future status. Bryologist 112:558-571.

Ridgway, R. (1884). The probable breeding place of Passerculus princeps. Auk 1:292-293.

Saunders. W.E. (1902). Birds of Sable Island. Ottawa Bat. 16:15-31.

Say, T. (1824-1828). American Entomology, or Descriptions of the Insects of North America, 3 vols. Philadelphia, PA.

Say, T. (1830-1834). American Conchology, or Descriptions of the Shells of North America Illustrated From Coloured Figures From Original Drawings Executed from Nature, Parts 1 - 6, New Harmony; Part 7, Philadelphia, 1836.

St. John, H. (1921). Sable Island, with a catalogue of its vascular plants. Proc. Boston Soc, Nat, Hist.36 (1):1-103.

van Soest, R. (2015) Heteromeyeniamacouni MacKay, 1900. In: van Soest, R.W.M; Boury-Esnault, N.; Hooper, J.N.A.; Rützler, K.; de Voogd, N.J.; Alvarez de Glasby, B.; Hajdu, E.; Pisera, A.B.; Manconi, R.; Schoenberg, C.; Janussen, D.; Tabachnick, K.R., Klautau, M.; Picton, B.; Kelly, M.; Vacelet, J.; Dohrmann, M.; Díaz, M.-C.; Cárdenas, P. (2015) Access: World Register of Marine Species: <http://www.marinespecies.org/aphia. php? $\mathrm{p}=$ taxdetails \&id $=191570$ on $2015-05-17>$.

Waiser, W. A. (1989). The Field Naturalists. John Macoun, the Geological Survey, and Natural Science. Toronto. Univ. Toronto Press. $x+21$ plates, $253 \mathrm{pp}$.

Willis, J. (1858). Mollusca of Sable Island, so far as ascertained up to 1858. P. 35 in: Gilpin 1858. 
Wilson, A. (1808-1814). American Ornithology; or the Natural History of the Birds of the United States: Illustrated with Plates Engraved and Colored from Original drawings taken from Nature. Bradford and Innskeep, Philadelphia, PA.

Wright, B. (1989). The fauna of Sable Island. Curatorial Report Number 68, Nova Scotia Museum, Halifax. 93 pp. 